\title{
KAJIAN KONSENTRASI LARUTAN PENYALUT (Susu Skim, Fero Fumarat dan Tiamin) DAN JENIS VARIETAS BERAS TERHADAP KANDUNGAN NUTRISI BERAS
}

\author{
Asep Dedy Sutrisno \\ Sumartin \\ Dian Komala Sari \\ Program Studi Teknologi Pangan Fakultas Teknik Universitas Pasundan, Jl. Dr. Setiabudhi No. 193, Bandung, 40153, \\ Indonesia.
}

Email : asepdedysutrisno@unpas.ac.id

\begin{abstract}
Abstrak
Penelitian ini bertujuan untuk meningkatkan kandungan protein, zat besi dan tiamin pada beras varietas IR 64-3 dan varietas IR 42 yang ditambahkan susu skim, fero fumarat dan tiamin sebagai larutan fortifikan sehingga dapat memenuhi kebutuhan zat gizi harian yang dibutuhkan untuk menekan timbulnya defisiensi vitamin dan mineral. Rancangan percobaan penelitian yang digunakan adalah Rancangan Acak Kelompok (RAK) dengan pola faktorial 3 x 2 dan ulangan sebanyak 4 kali. Faktor pertama adalah konsentrasi larutan fortifikan (f) terdiri dari f1 (7\%), f2 (14\%), dan f3 (21\%). Faktor kedua adalah varietas beras (v) terdiri dari v1 (IR 64-3) dan v2 (IR 42). Respon penelitian adalah analisis kimia meliputi kadar protein, kadar besi, kadar tiamin dan kadar air serta analisis organoleptik berdasarkan uji hedonik terhadap atribut warna, aroma dan rasa. Hasil penelitian menunjukkan bahwa konsentrasi larutan fortifikan dan varietas beras berbeda nyata terhadap kadar protein, kadar besi dan kadar tiamin pada fortifikasi beras varietas IR 64-3 dan IR 42. Interaksi antara konsentrasi larutan fortifikan dan varietas beras berbeda nyata terhadap kadar protein dan kadar tiamin pada beras fortifikasi. Hasil uji hedonik untuk beras fortifikasi dengan atribut warna menunjukkan konsentrasi fortifikan dan interaksinya tidak berbeda nyata terhadap beras fortifikasi. Sedangkan faktor varietas beras berbeda nyata terhadap beras fortifikasi. Dalam hal atribut warna menunjukkan konsentrasi fortifikan berbeda nyata terhadap beras fortifikasi sedangkan faktor varietas beras dan interaksinya tidak berbeda nyata terhadap beras fortifikasi. Dan dalam atribut rasa untuk nasi fortifikasi, menunjukkan konsentrasi fortifikan, varietas beras dan interaksinya tidak berbeda nyata terhadap nasi fortifikasi.
\end{abstract}

\begin{abstract}
This research aims to increase the protein, iron and thiamine on varieties IR 64-3 and IR 42, which added skim milk, ferrous fumarate and thiamine as a fortified solution to meet the daily nutrient requirements to reduced deficiency vitamin and mineral. The experimental design of this research was Randomized Block Design (RAK) with $3 \times 2$ factorial pattern and 4 replications. The first factor is fortified solution (f) consisting of f1 (7\%), f2 (14\%) and $\mathrm{f3}(21 \%)$. The second factor is rice varieties (v) consisting of v1 (IR 64-3) and v2 (IR 42). The responses of this study were the analysis of protein content, iron content and thiamine content, and organoleptic analysis based a hedonic test on color, flavor, and taste attributes. The results showed that the concentration of fortified solution and rice varieties against protein, iron and thiamine levels in fortified rice IR 64-3 and IR 42. The interaction between the concentration a fortified solution and rice varieties against protein and thiamine levels in fortified rice. The hedonic test results for fortified rice in color attributes showed the concentration of solution and interaction had no effect on fortified rice. While rice varieties had effect on fortified rice. In flavour attributes showed the concentration of solution had effect on fortified rice, While the rice varieties and interaction had no effect on fortified rice. And in the taste attributes showed for fortified rice, the concentration of solution, rice varieties and the interaction had no effect on fortified rice.
\end{abstract}

Keywords: Varieties IR 64, Varieties IR 42, Fortification, Protein, Iron, Thiamine.

\section{Pendahuluan}

Beras merupakan salah satu padian paling penting di dunia untuk konsumsi manusia. Di negara-negara Asia yang penduduknya padat, khususnya Bangladesh, Myanmar, Kamboja, Cina, Indonesia, Korea, Laos, Filipina, Sri Lanka, Thailand, dan Vietnam, beras merupakan pangan pokok. Sebanyak $75 \%$ masukan kalori harian masyarakat di negara-negara Asia tersebut berasal dari beras. Lebih dari 50\% penduduk dunia bergantung pada beras sebagai sumber kalori utama (FAO, 2001; Childs, 2004; dalam Haryadi, 2008). 
Beras di Indonesia bermacam-macam jenisnya. Ada beras yang dikelompokkan berdasarkan jenis atau kelompok varietas padi, berdasarkan cara processing, dan berdasarkan derajat penyosohannya (Annissa, 2007). Jenis beras yang banyak dikonsumsi masyarakat Indonesia adalah beras putih (milled rice).

Beras yang digunakan dalam penelitian ini adalah beras dari varietas yang berasal dari IRRI (International Rice Research Institute) yaitu IR 64 dan IR 42. Beras IR 64 merupakan salah satu varietas yang paling banyak dikonsumsi masyarakat, rata-rata produktivitas padi yang dihasilkan mencapai 5,0 Ton/ha GKG. Dalam 100 gram beras giling varietas IR 64 terdapat kandungan protein $8,25 \%$, lemak $0,45 \%$, karbohidrat 79,98\%, amilosa 23\%, dan besi 4,7 ppm. Sedangkan rata-rata produktivitas padi yang dihasilkan beras IR 42 mencapai 5,0 Ton/ha GKG. Dalam 100 gram beras giling varietas IR 42 mempunyai kadar air $11,82 \%$, protein $8,59 \%$, lemak $1,23 \%$, karbohidrat $89,40 \%$ dan besi 2,9 ppm (Balai Besar Penelitian Tanaman Padi, 2008).

Beras merupakan sumber energi yang tinggi akan karbohidrat dan berkontribusi memberikan persentase terbesar dalam pemenuhan kalori, namun pada beras memiliki kandungan protein, vitamin dan mineral yang rendah. Menurut Almatsier (2009), padi-padian dan hasilnya relatif rendah dalam protein. Protein pada padi-padian tidak komplit, dengan asam amino pembatas lisin. Kandungan lisin pada beras yaitu kurang lebih 4\% (Haryadi, 2008).

Susu skim merupakan sumber protein yang baik, protein susu skim mengandung asam amino esensial (Hardinsyah dan Martianto, 1989), untuk meningkatkan nilai gizi protein pada beras dapat dilakukan dengan menambahkan susu skim.

Menurut International Rice Research Institute di Filipina, nilai gizi beras perlu ditingkatkan lagi. Selama ini beras dikenal sebagai bahan pangan sumber energi, bukan sumber vitamin dan mineral yang penting bagi kesehatan. Sebagai zat gizi, vitamin dan mineral diperlukan tubuh dalam jumlah sedikit, namun ternyata mempunyai fungsi yang sangat penting bagi metabolisme tubuh sehingga perlu adanya upaya peningkatan kandungan zat besi dan tiamin dalam beras. Dalam hal ini untuk meningkatkan kandungan zat besi digunakan senyawa fero fumarat karena, senyawa ini secara organoleptik dapat diterima dan memiliki penyerapan yang baik dalam tubuh (Surahman, 2014) sedangkan untuk meningkatkan vitamin digunakan tiamin yang bersifat tidak mudah mengalami oksidasi serta berfungsi sebagai koenzim penting dalam sistem metabolisme tubuh (Budiyanto, 2009).

Berdasarkan angka kecukupan gizi (AKG) kebutuhan protein pada usia dewasa adalah 62-65 g perhari, zat besi 13-26 mg perhari dan tiamin 1,4 mg perhari. Untuk memenuhi kebutuhan asupan gizi harian (daily intake) dapat dilakukan pendekatan berbasis pangan (food based approach) yaitu dengan perbaikan makanan atau pangan dan fortifikasi pangan.

Fortifikasi adalah sebuah upaya yang sengaja dilakukan untuk menambahkan mikronutrien yang penting, yaitu vitamin dan mineral ke dalam makanan sehingga dapat meningkatkan kualitas nutrisi dari pasokan makanan dan bermanfaat bagi kesehatan masyarakat dengan resiko yang minimal untuk kesehatan (WHO, 2006).

Beras dipilih sebagai bahan pangan pembawa fortifikasi karena merupakan bahan pokok yang dikonsumsi penduduk Indonesia. Selain itu pada umumnya beras dimasak secara tunggal, tanpa penambahan bahan-bahan dan bumbu masakan lain. Oleh karena itu beras berpeluang besar untuk dapat difortifikasi. (Balai Besar Pasca Panen, 2006). Pemerintah Indonesia juga mencanangkan fortifikasi wajib pada produk beras harus mengandung tiamin, asam folat, zat besi, zink dan lain-lain (Sihotang, 2014).

Berdasarkan pada hal tersebut maka akan dilakukan proses fortifikasi pada beberapa jenis varietas beras dengan susu skim, fero fumarat dan tiamin.

Berdasarkan uraian dalam latar belakang penelitian, maka masalah yang dapat diidentifikasi adalah sebagai berikut:

1. Apakah kosentrasi larutan penyalut berpengaruh terhadap beras fortifikasi?

2. Apakah varietas beras berpengaruh terhadap beras fortifikasi?

3. Apakah interaksi antara konsentrasi larutan penyalut dan varietas beras berpengaruh terhadap beras fortifikasi?

Maksud dari penelitian ini adalah untuk meningkatkan kandungan protein, zat besi dan tiamin pada berbagai varietas beras yang ditambahkan susu skim, fero fumarat dan tiamin sebagai larutan penyalut sehingga dapat memenuhi kebutuhan zat gizi harian yang dibutuhkan.

Tujuan dari penelitian ini adalah untuk mengetahui kadar protein, zat besi dan tiamin pada beras yang difortifikasi dengan susu skim, fero fumarat dan tiamin sehingga dapat memenuhi angka kecukupan protein, zat besi dan tiamin harian yang dibutuhkan.

Penelitian ini diharapkan dengan adanya beras terfortifikasi dapat memenuhi angka kecukupan protein, menekan timbulnya anemia defisiensi besi dan defisiensi tiamin, serta dapat memberikan infomasi mengenai penambahan konsentrasi larutan penyalut (susu skim, fero fumarat dan tiamin) dan varietas beras terhadap kandungan nutrisi beras.

Fortifikasi pangan umumnya digunakan untuk mengatasi masalah gizi mikro pada jangka menengah dan panjang. Tujuan utamanya adalah untuk meningkatkan tingkat konsumsi dari zat gizi yang ditambahkan untuk meningkatkan status gizi populasi atau masyarakat. Fortifikasi pangan juga digunakan 
untuk menghapus dan mengendalikan defisiensi zat gizi dan gangguan yang diakibatkannya (Fidler,MC.,2003 ; Kanpairo, et al., 2012).

Efektivitas fortifikasi yang dapat diterima oleh masyarakat luas harus dilakukan dengan produk yang sering dikonsumsi. Beras merupakan bahan pangan yang paling banyak dikonsumsi di masyarakat sehingga memudahkan pelaksanaan program fortifikasi.

Menurut World Food Programme (2015), kandungan zat besi pada beras yang akan diperkaya zat besi kandungan besinya tidak boleh kurang dari 40 $\mathrm{mg} / \mathrm{kg}$ dan tidak boleh lebih dari $48 \mathrm{mg} / \mathrm{kg}$.

Hasil analisa kadar Fe pada beras varietas IR 64 kualitas 3 yang di fortifikasi tanpa perlakuan pencucian kemudian di semprotkan larutan penyalut yang mengandung fortifikan fero fumarat dengan konsentrasi $7 \%$ b/v, $14 \%$ b/v dan $21 \%$ b/v pada 1000 gram beras memiliki kadar besi $15,64 \mathrm{mg} / \mathrm{kg} ; 24,61$ $\mathrm{mg} / \mathrm{kg}$; dan $48,39 \mathrm{mg} / \mathrm{kg}$. Sedangkan beras yang diberi perlakuan pencucian kemudian dilakukan fortifikasi setelah itu beras yang difortifikasi kemudian dilakukan pencucian satu kali memiliki kadar besi $14,33 \mathrm{mg} / \mathrm{kg}$; 21,81 mg/kg ; dan 27, $62 \mathrm{mg} / \mathrm{kg}$ (Surahman, 2014).

Fortifikan zat besi yang direkomendasikan oleh WHO dalam berbagai kategori senyawa yaitu yang larut dalam air, kurang larut dalam air tetapi larut dalam asam encer, dan sama sekali tidak larut dalam air tetapi larut dalam asam encer (Darlan, 2012).

Menurut Allen L. et al (2006), menyatakan bahwa fero fumarat merupakan sumber zat besi yang banyak digunakan untuk fortifikasi sereal bayi. Fero fumarat termasuk kedalam senyawa besi sedikit larut dalam air, senyawa ini secara organoleptik dapat diterima, dan lebih stabil pada proses pengeringan vakum pada suhu $100^{\circ} \mathrm{C}$ (Fidler, 2003).

Tiamin tersedia dalam berbagai bentuk senyawa, dimana bentuk yang digunakan sebagai standar adalah tiamin hidroklorida. Tiamin hidroklorida mempunyai rumus formula $\mathrm{C}_{12} \mathrm{H}_{17} \mathrm{~N}_{4} \mathrm{OS}^{+} \mathrm{Cl}^{-} . \mathrm{HCl}$ dengan berat molekul 337,27 dan berbentuk tepung tidak berwarna. Tiamin hidroklorida mudah larut dalam air, alkohol tetapi tidak larut dalam eter, kloroform, benzene dan aseton. Tiamin hidroklorida cukup stabil dalam larutan asam kuat dan $\mathrm{pH} 3,5$, dapat dipanaskan sampai $120^{\circ} \mathrm{C}$ tanpa terjadi dekomposisi (Eitenmiller, et al., 2008).

Menurut Villareal dan Juliano (1989), menyatakan kandungan tiamin dari 30 varietas padi yang dikembangkan IRRI kisaran kandungan tiaminnya adalah 0,285 - 0,52 mg/100 gram (bobot basah).

Menurut acuan Label gizi pangan olahan (2016), angka kecukupan gizi harian yang dibutuhkan untuk asupan tiamin adalah 1,4 mg/hari.

Menurut Kyritsi et al (2011), beras yang difortifikasi dengan tiamin dan asam folat dengan metode penyemprotan penuh ke seluruh kernel dengan larutan vitamin pada suhu $35^{\circ} \mathrm{C}$ dan metode perendaman milled rice dengan larutan vitamin pada suhu $90^{\circ} \mathrm{C}$ selama 15 menit kemudian keduanya dilakukan pengeringan dan pemasakan. Setelah dimasak, retensi vitamin lebih tinggi untuk metode perendaman daripada metode penyemprotan. Hal ini disebabkan karena dengan metode penyemprotan menghasilkan difusi vitamin ke bagian kernel sehingga selama proses memasak, vitamin berada jauh dari permukaan kernel atau permukaan air dan lebih terlindungi dari proses pencucian.

Kehilangan tiamin pada beras dan produk pasta disebabkan karena panas,oksigen, cahaya dan kelembaban selama perendaman dan pengeringan. Oleh karena itu produk harus diperkaya dengan tiamin minimal $20 \%$ lebih dari kebutuhan untuk menggantikan kehilangan selama pemrosesan (Vandresek dan Warthesen, 1987).

Mikroenkapsulasi adalah suatu proses penyalutan partikel-partikel suatu zat inti berbentuk padat, cair maupun gas dengan bahan penyalut khusus yang membuat partikel-partikel inti mempunyai sifat fisika dan kimia seperti yang dikehendaki (Yudha, 2008).

Proses mikroenkapsulasi terdiri dari dua tahap yaitu pencampuran bahan inti dan larutan membentuk materi pembentuk dinding dan pengeringan emulsi yang terbentuk (Halim, 2013).

Zat aktif yang terkurung di dalam mikrokapsul disebut inti atau core, dimana inti ini dapat berwujud padat atau cair dengan sifat permukaan hidrofilik atau hidrofobik. Sedangkan dinding pengkapsul mikrokapsul disebut skin, shell atau pengkapsul (Halim, 2013).

Menurut Versich (2000) dalam Badarudin (2006), banyak bahan enkapsulat yang berasal dari polisakarida seperti gum arabic, carboximetilcelulosa, dextrin, maltodextrin, karagenan dan agar.

Bahan pengkapsul yang digunakan pada umumnya dari golongan karbohidrat seperti maltodekstrin. Bahan ini memberikan perlindungan yang baik terhadap kerusakan oksidatif, namun tidak memiliki sifat pembentuk film yang dibutuhkan dalam pelapisan beras untuk tujuan fortifikasi (Yuliani, 2011).

Protein susu seperti susu skim dapat memberikan sifat ketahanan terhadap kerusakan oksidatif sekaligus memiliki sifat pembentuk film agar mikrokapsul yang dilapiskan pada permukaan beras tidak mudah larut dalam air selama proses pencucian dan pemasakan (Yuliani, 2011).

Proses fortifikasi beras dilakukan dengan cara menyemprotkan suspensi mikrokapsul kedalam permukaan beras menggunakan mesin pemoles beras hingga permukaan butir beras tersalut sepenuhnya dengan mikrokapsul (Cahyadi,2004).

Metode enrichment yang menyangkut penambahan zat-zat gizi ke produk hasil penggilingan. Dalam teknik ini terdapat dua kelompok enrichment "jenis tepung" dan "jenis biji utuh". Dalam enrichment jenis tepung, campuran vitamin dan mineral berbentuk tepung dalam jumlah 1, 0.5 atau $0.25 \mathrm{oz}$. per $100 \mathrm{lbs}$ of rice (a w/w 
ratio of 1:1600, 1:3200 atau 1:6400) ditambahkan ke dalam beras giling. Penambahan premiks dilakukan segera setelah penggilingan karena adanya panas dan uap air dalam permukaan beras akan mempermudah pelekatan tepung vitamin dan mineral. Pada metode kedua, campuran vitamin dan mineral bentuk tepung ditambahkan ke dalam beras giling, kemudian diikuti dengan proses coating menggunakan bahan tidak larut air. Kemudian sebanyak $0,5 \%$ beras yang telah difortifikasi tersebut dicampurkan ke beras yang tidak difortifikasi sehingga jumlahnya standar beras fortifikasi. Di Amerika Serikat misalnya, standar beras fortifikasi adalah 2,0-4,0 mg tiamin dan 13-26 mg zat besi per $100 \mathrm{lb}$ beras (Koswara, 2009).

Grain type or coated grain enrichment dapat dilakukan dengan melakukan spraying larutan premix vitamin dan mineral ke dalam beras yang ditempatkan dalam silinder berputar, diikuti dengan pengeringan menggunakan udara panas, penambahan bahan tidak larut air, penambahan zat besi, dan penambahan kedua dari bahan tidak larut air (Koswara, 2009).

Berdasarkan latar belakang permasalahan dan didukung oleh kerangka pemikiran dapat diajukan hipotesis sebagai berikut :

1. Diduga bahwa konsnetrasi larutan penyalut berpengaruh terhadap beras fortifikasi.

2. Diduga bahwa varietas beras berpengaruh terhadap beras fortifikasi.

3. Diduga interaksi antara larutan penyalut dan varietas berpengaruh terhadap beras fortifikasi.

\section{Metode Penelitian}

\section{Penelitian Pendahuluan}

Penelitian pendahuluan tahap pertama adalah melakukan analisis kimia (kadar protein, kadar besi dan kadar tiamin) terhadap bahan baku beras dari dua varietas yaitu IR 64-3 dan IR 42.

Penelitian pendahuluan tahap kedua adalah menghitung angka kecukupan protein, zat besi dan tiamin yang dibutuhkan untuk pembuatan beras fortifikasi. Selanjutnya adalah pembuatan bahan pengkapsul yang terdiri dari campuran maltodekstrin, susu skim bubuk, fero fumarat dan tiamin. Maltodekstrin dan susu skim dicampukan dengan $50 \mathrm{ml}$ akuades kemudian ditambahkan fero fumarat $0,04 \%$ dan $0,06 \%$ tiamin yang kemudian dilakukan pengeringan dengan tunnel dryer. Bahan pengkapsul dilakukan pengujian kadar air, protein, besi dan tiamin.

\section{Penelitian Utama}

Penelitian utama dilakukan dengan menggunakan bahan pengkapsul dari hasil penelitian pendahuluan, maka dilakukan perlakuan untuk penelitian utama. Beras putih dari dua varietas yaitu IR 64-3 dan IR 42 dilakukan fortifikasi dengan cara menyemprotkan larutan fortifikan yang mengandung susu skim, fero fumarat dan tiamin. Konsentrasi larutan fortifikan untuk masing-masing perlakuan adalah $7 \% \mathrm{~b} / \mathrm{v}, 14 \%$ b/v dan $21 \%$ b/v.

Rancangan perlakuan pada penelitian ini terdiri dari dua faktor yaitu konsentrasi larutan fortifikan (f) yang terdiri dari 3 taraf dan varietas beras (v) yang terdiri dari 2 taraf, yaitu:

1. Faktor konsentrasi larutan fortifikan (f) yang digunakan terdiri dari 3 taraf yaitu:

$\mathrm{f}_{1}, \mathrm{f}_{2}, \mathrm{f}_{3}=7 \%, 14 \%, 21 \%$

2. Faktor varietas beras (v) yang digunakan terdiri dari 2 taraf yaitu:

$\mathrm{v}_{1}=$ IR 64-3

$\mathrm{v}_{2}=\operatorname{IR} 42$

Rancangan percobaan yang dilakukan pada penelitian ini adalah Rancangan Acak Kelompok (RAK) dengan pola faktorial 3x2 dengan 4 kali ulangan, sehingga didapatkan 24 kali percobaan.

Rancangan respon yang akan diamati terhadap produk beras fortifikasi adalah respon kimia dan respon organoleptik. Respon kimia terhadap produk beras fortifikasi yang akan diamati adalah penentuan kadar protein dengan menggunakan metode kjedahl (AOAC, 2005), kadar besi menggunakan spektrofotometri UV-VIS (AOAC, 2005), penentuan kadar tiamin menggunakan titrasi argentometri (Sumantri, 2007) dan penentuan kadar air menggunakan metode gravimetri (AOAC, 2005). Respon organoleptik yaitu uji hedonik terhadap warna dan aroma sedangkan untuk rasa dilakukan proses pemasakan menjadi nasi.

\section{Prosedur Penelitian}

Deskripsi Penelitian Pendahuluan

Prosedur Penelitian Tahap I

Prosedur penelitian tahap pertama yang dilakukan adalah analisis terhadap bahan baku beras yang meliputi analisis kadar protein, kadar besi dan kadar tiamin.

\section{Prosedur Penelitian Tahap II}

1. Persiapan bahan

Bahan yang digunakan dalam pembuatan bahan pengkapsul ini adalah maltodekstrin, susu skim bubuk, fero fumarat, tiamin dan akuades. Bahan-bahan yang telah disiapkan kemudian ditimbang dengan berat yang telah ditentukan.

2. Homogenisasi I

Maltodekstrin dan susu skim dilakukan pencampuran kemudian dilakukan homogenisasi hingga homogen selama 15 menit menggunakan magnetic stirrer.

\section{Hidrasi}

Pasta penyalut di hidrasi selama satu malam pada ruangan cold room dengan suhu $4^{\circ} \mathrm{C}$ selama 1 malam. Tujuan dari proses hidrasi ini adalah untuk menurunkan suhu larutan penyalut sehingga diharapkan meminimalisir kerusakan tiamin dan $\mathrm{Fe}$ yang akan ditambahkan pada proses selanjutnya.

4. Homogenisasi II 
Fero fumarat sebanyak 300 ppm dan tiamin 400 ppm ditambahkan ke dalam pasta penyalut dingin kemudian dilakukan homogenisasi kembali menggunakan magnetic stirrier selama 10 menit untuk menyeragamkan bentuk dari campuran penyalut dan agar partikel fero fumarat dan tiamin dapat berikatan sempurna dengan partikel susu skim dan maltodekstrin. 5. Pencetakan

Setelah seluruh bahan telah tercampur dengan baik kemudian dilakukan pencetakan diatas loyang untuk dikeringkan.

6. Pengeringan

Hasil dari homogenisasi diletakkan dalam bentuk lapisan tipis pada tray kemudian dilakukan pengeringan pada tunnel dryer pada suhu $65^{\circ} \mathrm{C}$ selama \pm 3 jam.

7. Penggilingan

Bahan pengkapsul yang telah dikeringkan kemudian dilakukan proses temperingpada suhu $28^{\circ} \mathrm{C}$ selama \pm 10 menit, kemudian dilakukan penghalusan dengan memasukkan lapisan kering ke dalam blender selama 1-2 menit.

\section{Pengujian Kimia}

Terhadap produk bahan pengkapsul ini dilakukan analisis kadar air menggunakan metode gravimetri, kadar protein menggunakan metode kjedahl, kadar besi menggunakan spektrofotometri UV-Vis dan kadar tiamin menggunakan titrasi argentometri.

\section{Deskripsi Penelitian Utama}

1. Persiapan Bahan Baku

Bahan baku yang digunakan dalam pembuatan fortifikasi beras yaitu beras IR, Beras putih dari varietas IR 64-3 dan IR 42 serta bahan pengkapsul yang telah dibuat pada penelitian pendahuluan.

2. Sortasi

Beras dilakukan sortasi, yaitu membersihkan beras dari kotoran seperti batu dan kulit gabah yang terbawa dan memisahkan beras yang patah.

3. Penimbangan

Dua jenis varietas beras putih yang sudah dibeli kemudian ditambang masing-masing dengan berat 100 gram.

4. Membuat suspensi mikrokapsul

Ditimbang sebanyak 0,7 gram, 1,4 gram dan 2,1 gram bahan pengkapsul bubuk, kemudian masingmasing dilarutkan dengan akuades.

5. Coating (Pemolesan)

Beras dimasukkan ke dalam alat molen dryer, suspensi mikrokapsul disemprotkan kepermukaan beras sambil diaduk dalam molen dryer. Proses dilakukan hingga larutan suspensi mikrokapsul habis.

6. Pengujian respon kimia dan organoleptik

Beras yang telah selesai dilakukan coating kemudian dilakukan analisis kadar protein, zat besi, tiamin dan kadar air. Sedangkan untuk uji organoleptik dilakukan pada atribut warna dan aroma

7. Pencucian Beras
Sampel beras fortifikasi yang terpilih dilakukan pencucian dengan cara beras diaduk searah putaran jarum jam sebanyak satu kali putaran.

8. Pemasakan

Sampel beras fortifikasi yang terpilih kemudian dimasak menggunakan rice cooker dengan suhu $134^{\circ} \mathrm{C}$ selama \pm 20 menit. Lalu beras yang telah dimasak disimpan di rice cooker.

9. Pengujian respon organoleptik

Nasi fortifikasi dari sampel beras fortifikasi dilakukan uji organoleptik terhadap rasa.

\section{Hasil dan Pembahasan}

\section{Penelitian Pendahuluan}

Penelitian Pendahuluan Tahap I

Penelitian pendahuluan yang dilakukan terdiri dari dua tahap. Tahap pertama adalah analisis terhadap bahan baku beras. Analisis yang dilakukan pada penelitian pendahuluan ini untuk mendapatkan hasil kadar protein, kadar besi dan tiamin pada beras varietas IR 64-3 dan IR 42.

Tabel 1. Hasil Analisis Bahan Baku Beras

\begin{tabular}{|c|c|c|}
\hline Komponen & IR 64-3 & IR 42 \\
\hline Protein & $2,08 \%$ & $3,45 \%$ \\
Fe & $0,16 \mathrm{mg} / \mathrm{kg}$ & $0,73 \mathrm{mg} / \mathrm{kg}$ \\
Tiamin & $421,5 \mathrm{ppm}$ & $419,40 \mathrm{ppm}$ \\
\hline
\end{tabular}

Protein merupakan penyusun utama kedua pada beras setelah pati. Protein adalah salah satu makronutrien yang berperan dalam proses pembentukan biomolekul. Protein adalah suatu senyawa yang sebagian besar terdiri atas unsur nitrogen. Jumlah unsur ini dapat digunakan sebagai dasar penentuan kadar protein dalam beras (Haryadi, 2008). Penentuan kadar protein pada analisis ini dilakukan menggunakan metode kjedahl. Berdasarkan data Tabel 14, beras varietas IR 64-3 memiliki kadar protein $2,08 \%$ dan varietas IR $423,45 \%$.

Beras mengandung mineral penting yang diperlukan oleh tubuh dalam jumlah sedikit. Mineral pada beras terdiri atas unsur-unsur kalsium, klor, natrium, silika dan besi (Haryadi, 2008). Penentuan kadar besi pada analisis ini dilakukan dengan menggunakan spektrofotometri UV-VIS. Berdasarkan data Tabel 14, beras varietas IR 64-3 memiliki kadar besi $0,16 \mathrm{mg} / \mathrm{kg}$ dan varietas IR $420,73 \mathrm{mg} / \mathrm{kg}$.

Vitamin adalah zat-zat organik kompleks yang dibutuhkan oleh tubuh, oleh karena itu harus didatangkan dari makanan. Setiap vitamin mempunyai tugas spesifik di dalam tubuh. Vitamin adalah zat organik maka dapat rusak karena penyimpanan dan pengolahan (Almatsier,2009). Vitamin pada beras yang terutama ialah tiamin, riboflavin, niasin dan piridoksin. Berdasarkan data Tabel 14, beras varietas IR 64-3 memiliki kadar tiamin 421,5 ppm dan varietas IR 42419,40 ppm. 
Komposisi kimia pada beras giling dapat dibedakan oleh varietas beras, kondisi lingkungan pada saat pertumbuhan tanaman dan perbedaan tingkat penyosohan. Beras yang digunakan dalam penelitian ini merupakan milled rice, yaitu beras yang melalui proses penggilingan. Kandungan protein, vitamin dan besi berada dilapisan aleuron. Aleuron adalah lapisan terluar yang sering kali ikut terbuang dalam proses pemisahan kulit. Setiap jenis varietas padi memiliki ketebalan yang berbeda-beda. Sebagian dari protein, vitamin dan mineral akan terbawa dalam dedak, sehingga kadar komponen-komponen tersebut di dalam beras giling menurun. Selain itu penyosohan yang lebih lama akan menurunkan kandungan protein beras.

\section{Penelitian Pendahuluan Tahap II}

Penelitian tahap kedua yaitu pembuatan bahan pengkapsul. Dalam penelitian ini digunakan susu skim dan maltodekstrin sebagai bahan dasar pembuatan bahan pengkapsul serta penambahan fero fumarat dan tiamin yang menghasilkan bahan pengkapsul. Hasil analisis karakteristik bahan pengkapsul dapat dilihat dalam Tabel 2.

Tabel 2. Karakteristik Bahan Pengkapsul

\begin{tabular}{|c|c|}
\hline $\begin{array}{c}\text { Karakkteristik bahan } \\
\text { pengkapsul }\end{array}$ & Nilai \\
\hline Kadar air & $4,85 \%$ \\
Kadar protein & $19,51 \%$ \\
Kadar besi & $180,5 \mathrm{mg}$ \\
Kadar tiamin & $8514,3 \mathrm{ppm}$ \\
\hline
\end{tabular}

Kadar air bahan pengkapsul dipengaruhi oleh susu skim dan maltodekstrin yang digunakan. Maltodekstrin dapat mengikat air bebas, selain itu maltodekstrin juga dapat digunakan sebagai bahan pelindung fero fumarat dan tiamin, bahan pengemulsi serta bahan pengisi, tetapi daya emulsifikasi dari maltodekstrin kurang baik. Untuk menutupi kelemahan dari sifat maltodekstrin tersebut maka maltodekstrin dicampurkan dengan susu skim. Susu skim berfungsi sebagai emulsifier karena kandungan proteinnya memiliki sifat mengemulsi yang dapat membuat ikatan mikrokapsul semakin kompak sehingga dapat sebagai pembentuk film, sedangkan karbohidrat sebagai filler dan pembentuk matriks (Surahman, 2014).

Proses pembuatan bahan pengkapsul meliputi tahapan pencampuran antara maltodekstrin dan susu skim, homogenisasi, hidrasi, homogenisasi kembali dan pengeringan (Surahman, 2014).

Pencampuran maltodekstrin dan susu skim dengan akuades bertujuan untuk mendapatkan pasta mikrokapsul. Agar mikrokapsul tercampur sempurna maka dilakukan homogenisasi. Selanjutnya adalah tahap hidrasi dalam cooling room bersuhu $4^{\circ} \mathrm{C}$ selama satu malam yang bertujuan untuk menurunkan suhu pasta mikrokapsul, hal ini penting untuk dilakukan agar fero fumarat dan tiamin yang akan ditambahkan tidak mudah rusak akibat suhu yang naik karena adanya energi panas dari alat homogenizer (Surahman, 2014).

Fero fumarat dan tiamin (zat gizi mikro) yang telah ditambahkan ke dalam pasta mikrokapsul di homogenisasi kembali agar partikel zat gizi mikro tersebut dapat berikatan sempurna dengan partikel maltodekstrin dan susu skim tanpa merusak kandungan gizinya dalam pasta mikrokapsul. Proses pengeringan pasta mikrokapsul dengan alat tunnel dryer berfungsi untuk menghilangkan sebagian kadar air yang terkandung di dalam pasta penyalut, sehingga diperoleh produk bahan pengkapsul. Kadar air bebas akan menguap karena adanya udara panas yang dialirkan dari alat tunnel dryer, sehingga terbentuk bahan pengkapsul. Analisis kadar air, protein, besi dan tiamin dalam bahan pengkapsul perlu dilakukan agar dapat mengetahui kadar air, protein, besi dan tiamin dalam bahan pengkapsul (Surahman, 2014).

\section{Penelitian Utama}

Respon Kimia

Analisis Kadar Protein

Kadar protein dalam beras fortifikasi ditentukan menggunakan metode kjedahl. Berdasarkan perhitungan analisis variansi, diketahui bahwa konsentrasi larutan fortifikan, varietas beras dan interaksi antara keduanya berpengaruh nyata terhadap kadar protein beras fortifikasi. Pengaruh interaksi terhadap kadar protein beras fortifikasi dapat dilihat pada Tabel 3.

Tabel 3. Pengaruh Interaksi Konsentrasi Larutan fortifikan dan Varietas Beras terhadap Kadar Protein Beras Fortifikasi

\begin{tabular}{|c|c|c|}
\hline \multirow{2}{*}{$\begin{array}{c}\text { Konsentrasi } \\
\text { Fortifikan (F) }\end{array}$} & \multicolumn{2}{|c|}{ Varietas Beras (V) } \\
\cline { 2 - 3 } f1 (7\%) & v1 (IR 64-3) & v2 (IR 42) \\
\hline & $\begin{array}{c}3,805 \% \\
\text { a }\end{array}$ & $\begin{array}{c}4,963 \% \\
\text { b }\end{array}$ \\
\hline f2 (14\%) & $\begin{array}{c}5,110 \% \\
\text { a }\end{array}$ & $\begin{array}{c}6,483 \% \\
\text { b }\end{array}$ \\
\hline & $\begin{array}{c}\text { C } \\
\text { f3 (21\%) }\end{array}$ & $\begin{array}{c}\text { C,660 } \% \\
\text { a }\end{array}$ \\
\end{tabular}

Protein adalah makromolekul yang tersusun atas unit-unit asam amino satu sama lainnya melalui ikatan peptide (Winarno,2002). Protein berperan penting untuk pertumbuhan dan pemeliharaan jaringan tubuh dengan kebutuhan protein sebesar kurang lebih 1 gram per $\mathrm{kg}$ berat badan orang dewasa (Almatsier, 2009). Berdasarkan Tabel 16, menunjukkan bahwa fortifikasi beras dengan susu skim akan meningkatkan kandungan protein beras.

Semakin tinggi konsentrasi larutan fortifikan yang diberikan maka semakin tinggi kadar protein pada beras fortifikasi. Hal ini disebabkan oleh konsentrasi 
bahan fortifikan yang ditambahkan semakin meningkat. Menurut Buckle (1987), penambahan susu skim bertujuan untuk meningkatkan kadar protein dan juga meningkatkan nilai gizi. Menurut Depkes RI (2012), kandungan protein yang relatif tinggi di dalam susu skim yaitu sebesar 3,5 gram merupakan sumber protein yang secara otomatis akan meningkatkan kadar protein pada beras fortifikasi. Selain itu dalam susu skim juga tinggi akan kandungan kalsium yaitu $123 \mathrm{mg}$ sehingga dapat juga meningkatkan kandungan kalsium dalam beras fortifikasi.

\section{Analisis Kadar Besi}

Fortifikasi beras dilakukan dengan jenis fortifikan fero fumarat. Sifat fero fumarat sedikit larut dalam air dan larut baik dalam asam. Kelarutan fero fumarat dalam airnya hanya $0,14 \mathrm{~g} / 100 \mathrm{~cm}^{3}$. Fero fumarat biasa digunakan sebagai fortifikan pada makanan kering tanpa pelarutan (Adriana, 2015).

Berdasarkan perhitungan analisis variansi, diketahui bahwa konsentrasi larutan penyalut berbeda nyata terhadap kadar besi beras fortifikasi. Hasil uji lanjut dapat dilihat pada Tabel 4.

Tabel 4. Pengaruh Konsentrasi Larutan Fortifikan terhadap Kadar Besi pada Beras Fortifikasi

\begin{tabular}{|c|c|c|}
\hline $\begin{array}{l}\text { Konsentrasi penyalut } \\
\text { (F) }\end{array}$ & Rata-rata & \\
\hline $\mathrm{f} 1(7 \%)$ & $12,409 \mathrm{mg} / \mathrm{kg}$ & $\mathrm{a}$ \\
\hline $\mathrm{f} 2(14 \%)$ & $25,589 \mathrm{mg} / \mathrm{kg}$ & $\mathrm{b}$ \\
\hline f3 $(21 \%)$ & $36,841 \mathrm{mg} / \mathrm{kg}$ & $\mathrm{c}$ \\
\hline
\end{tabular}

Dari Tabel 4 diatas, dapat diketahui konsentrasi penyalut $7 \%$ memiliki rata-rata kadar besi 12,409 $\mathrm{mg} / \mathrm{kg}$; konsentrasi penyalut $14 \%$ memiliki rata-rata kadar besi $25,589 \mathrm{mg} / \mathrm{kg}$ dan konsentrasi $21 \%$ memiliki rata-rata kadar besi $36,841 \mathrm{mg} / \mathrm{kg}$. Sehingga dapat disimpulkan bahwa semakin tinggi konsentrasi larutan fortifikan yang diberikan maka semakin tinggi kadar besi pada beras fortifikasi. Hal ini disebabkan oleh konsentrasi bahan fortifikan yang ditambahkan semakin meningkat. Kebutuhan asupan Fe per hari berdasarkan acuan label gizi pangan olahan adalah 22 mg sehingga dapat diketahui bahwa konsentrasi penyalut $14 \%$ adalah konsentrasi yang mendekati dengan kebutuhan asupan Fe per hari.

Proses mikroenkapsulasi pada fortifikan, dalam hal ini fero fumarat secara langsung memberikan perlindungan sehingga dapat mengurangi dampak kehilangan selama pengolahan. Mikroenkapsulasi zat besi dimaksudkan agar memodifikasi warna zat besi sehingga tidak berwarna dan mempermudah penggunaan zat besi dalam fortifikasi (Komari, 1995). Selain itu Fe berada dalam bentuk mikrokapsul yang bertindak sebagai barrier, mencegah interaksi antara zat besi dengan udara. Hal ini merupakan suatu keunggulan enkapsulasi. Apabila salah satu fortifikan tidak disalut maka kemungkinan terjadi interaksi antar fortifikan atau antar fortifikan dengan udara yang akan mengkatalisis terjadinya perubahan warna dan bau karat (Said, 2006).

Tabel 5. Pengaruh Varietas Beras terhadap Kadar Besi pada Beras Fortifikasi

\begin{tabular}{|c|c|}
\hline Varietas beras (V) & Rata-rata \\
\hline v1 (IR 64-3) & $24,654 \mathrm{mg} / \mathrm{kg}$ \\
\hline v2 (IR 42) & $25,238 \mathrm{mg} / \mathrm{kg}$ \\
\hline
\end{tabular}

Dari Tabel 5 diatas, dapat disimpulkan bahwa varietas beras berbeda nyata terhadap kadar besi fortifikasi, dimana varietas IR 42 memiliki rata-rata kadar besi lebih tinggi, yaitu 25,238 mg/kg dibandingkan dengan varietas IR 64-3 yaitu 24,654 $\mathrm{mg} / \mathrm{kg}$. Berdasarkan kebutuhan asupan Fe per hari menurut acuan label gizi pangan olahan adalah $22 \mathrm{mg}$ sehingga dapat diketahui bahwa varietas IR 64-3 dan IR 42 yang telah dilakukan fortifikasi telah mencapai kebutuhan Fe harian yang dianjurkan.

\section{Analisis Kadar Tiamin}

Vitamin B1 atau tiamin merupakan precursor dari kofaktor tiamin difosfat yang diperlukan oleh berbagai enzim yang berpartisipasi dalam metabolisme karbohidrat dan asam amino (Jordan 2003 ; Settembre et al ; Nosaka 2006). Berdasarkan perhitungan analisis variansi, diketahui bahwa konsentrasi larutan fortifikan, varietas beras dan interaksi antara keduanya berpengaruh nyata terhadap kadar tiamin beras fortifikasi. Pengaruh interaksi terhadap kadar tiamin beras fortifikasi dapat dilihat pada Tabel 6 .

Tabel 6. Pengaruh Interaksi Konsentrasi Larutan

\begin{tabular}{|c|c|c|}
\hline \multicolumn{3}{|c|}{ Fortifikan dan } \\
\hline \multirow{2}{*}{$\begin{array}{c}\text { Konsentrasi } \\
\text { Fortifikan (F) }\end{array}$} & \multicolumn{2}{|c|}{ Varietas Beras (V) } \\
\hline & v1 (IR 64-3) & v2 (IR 42) \\
\hline f1 $(7 \%)$ & $\begin{array}{c}\text { A } \\
\text { b }\end{array}$ & $\begin{array}{c}\text { A } \\
\text { 969,847 ppm } \\
\text { a }\end{array}$ \\
\hline f2 (14\%) & $\begin{array}{c}\text { B } \\
\begin{array}{c}1275,087 \mathrm{ppm} \\
\mathrm{b}\end{array} \\
\end{array}$ & $\begin{array}{c}\text { B } \\
1247,707 \text { ppm } \\
a \\
\end{array}$ \\
\hline f3 $(21 \%)$ & $\begin{array}{c}1537,750 \mathrm{ppm} \\
\mathrm{b}\end{array}$ & $\begin{array}{c}\mathrm{C} \\
1450,040 \mathrm{ppm} \\
\mathrm{a} \\
\end{array}$ \\
\hline
\end{tabular}

Kadar Tiamin Beras Fortifikasi

Berdasarkan Tabel 6, menunjukkan bahwa fortifikasi beras dengan tiamin meningkatkan kandungan tiamin beras. Semakin tinggi konsentrasi larutan fortifikan yang diberikan maka semakin besar kadar tiamin pada kedua jenis varietas beras yang dilakukan fortifikasi. Hal ini disebabkan oleh 
konsentrasi larutan penyalut yang ditambahkan semakin meningkat.

Vitamin B tidak dapat dibuat oleh tubuh dalam jumlah yang cukup. Oleh karena itu harus diperoleh dari bahan pangan yang dikonsumsi misalnya beras. Kadar tiamin dalam beras giling lebih rendah dari beras tumbuk.Kandungan tiamin dalam beras giling sekitar $0,12 \mathrm{mg} / 100 \mathrm{~g}$ sampel sehingga perlu dilakukan fortifikasi pada beras dengan menggunakan tiamin.

Tiamin bersifat mudah larut dalam air, sangat tidak stabil pada $\mathrm{pH}$ alkali, kestabilan bergantung pada tingkat pemanasan dan sifat matrik bahan pangan. Tiamin lebih sensitif terhadap panas dibandingkan riboflavin (Leskova et al, 2006). Tiamin dari beras fortifikasi diberikan untuk menambah kecukupan asupan harian akan tiamin. Berdasarkan acuan label gizi pangan olahan kebutuhan tiamin adalah 1,4 mg.

\section{Analisis Kadar Air}

Kadar air dalam bahan makanan mempengaruhi daya tahan makanan terhadap serangan mikrobiologi yang dinyatakan dengan $a_{w}$, yaitu jumlah air bebas yang dapat digunakan oleh mikroorganisme untuk pertumbuhannya. Berbagai mikroorganisme mempunyai $a_{w}$ agar dapat tumbuh dengan baik (Winarno, 2008).

Kandungan air sangat penting dalam menentukan daya awet dari bahan makanan karena mempengaruhi sifat fisik, kimia, perubahan mikrobiologi dan perubahan enzimatis (Winarno, 2008). Kadar air produk berhubungan dengan daya simpannya. Semakin rendah kadar air suatu produk maka daya simpannya diperkirakan akan lebih lama (Yustiani dan Setiawan, 2013).

Berdasarkan perhitungan analisis variansi, diketahui bahwa konsentrasi larutan fortifikan berbeda nyata terhadap kadar air beras fortifikasi. Hasil uji lanjut dapat dilihat pada Tabel 7.

Tabel 7. Pengaruh Konsentrasi Larutan Penyalut terhadap Kadar Air pada Beras Fortifikasi

\begin{tabular}{|c|rl|}
\hline Konsentrasi penyalut (F) & Rata-rata (Taraf 5\%) \\
\hline f3 (21\%) & $12,818 \%$ & $\mathrm{a}$ \\
f2 (14\%) & $13,380 \%$ & $\mathrm{~b}$ \\
f1 (7\%) & $13,695 \%$ & $\mathrm{c}$ \\
\hline
\end{tabular}

Dari Tabel 7 diatas, dapat disimpulkan bahwa konsentrasi larutan fortifikan berpengaruh terhadap kadar air fortifikasi, dimana konsentrasi $21 \%$ memiliki rata-rata kadar air 12,818\%; konsentrasi $14 \%$ memiliki rata-rata kadar air $13,380 \%$ dan pada konsentrasi $7 \%$ memiliki rata-rata kadar air $13,695 \%$. Menurut SNI 6128-2015 syarat kadar air beras giling maksimal adalah $15 \%$, sehingga beras yang dilakukan fortifikasi dengan konsentrasi 7\%, $14 \%$ dan $21 \%$ memiliki kandungan air yang telah memenuhi SNI yang telah ditetapkan karena memiliki nilai rata-rata kadar air dibawah $15 \%$.

\section{Respon Organoleptik}

Produk yang dihasilkan pada penelitian utama dilakukan penilaian organoleptik menggunakan uji hedonik terhadap warna dan aroma pada beras fortifikasi serta untuk rasa dilakukan proses memasak menjadi nasi. Uji hedonik ini akan dilakukan oleh 30 panelis.

Warna

Warna merupakan suatu sifat bahan yang dianggap berasal dari penyebaran spektrum sinar. Warna bukan merupakan suatu zat atau benda melainkan suatu sensasi seseorang karena adanya rangsangan dari seberkas energi radiasi yang jauh ke retina mata (Kartika, 1988).

Karakteristik suatu bahan sering kali dinilai dari penampilan fisik terutama warna. Warna merupakan faktor penilaian mutu bahan pangan secara visual yang tampil lebih dahulu dan terkadang merupakan faktor yang menentukan kualitas suatu makanan (Winarno, 2002). Menurut Soekarto (1985), warna dapat membuat suatu produk pangan menjadi manarik. Bagi produk pangan warna merupakan daya tarik utama sebelum konsumen mengenal dan menyukai sifat-sifat lainnya seperti aroma, rasa, tekstur dan sebagainya.

Berdasarkan perhitungan analisis variansi (Lampiran 16), terhadap analisis uji skala hedonik pada atribut warna diketahui bahwa faktor konsentrasi fortifikan (f) dan interaksinya tidak berbeda nyata terhadap beras fortifikasi. Sedangkan faktor varietas beras (v) berbeda nyata terhadap beras fortifikasi sehingga perlu dilakukan uji lanjut Duncan. Hasil uji lanjut dapat dilihat pada Tabel 8.

Tabel 8. Pengaruh Varietas Beras terhadap Nilai Kesukaan Warna pada Beras Fortifikasi

\begin{tabular}{|c|r|}
\hline Varietas Beras (V) & Rata-rata (Taraf 5\%) \\
\hline v1 (IR 64-3) & 4,012 a \\
v2 (IR 42) & $4,100 \quad$ b \\
\hline
\end{tabular}

Dari Tabel 8 diatas dapat diambil kesimpulan bahwa dalam hal warna beras fortifikasi yang dihasilkan panelis memberikan penilaian yang lebih rendah pada varietas IR 64-3 dibandingkan IR 42. Nilai warna beras mempunyai korelasi positif dengan kadar amilosa yang menentukan warna putih beras (Juliano, 1994). Menurut Balai Besar Penelitian Tanaman Padi (2009), varietas IR 64-3 memiliki kadar amilosa 24,1\% sedangkan varietas IR 42 memiliki kadar amilosa $27 \%$ sehingga varietas IR 42 memiliki warna lebih putih dari varietas IR 64-3. Selain itu faktor yang mempengaruhi warna putih beras adalah derajat sosoh. Menurut SNI (2015), persyaratan mutu beras kelas satu, dua dan tiga memiliki derajat sosoh $95 \%$, 90\% dan $80 \%$. Semakin lama beras disosoh semakin putih warnanya karena banyak lapisan aleuron yang hilang (Wang et al, 2002). 
Aroma

Bau-bauan (aroma) dapat di definisikan sebagai suatu yang dapat diamati dengan indera pembau. Untuk dapat menghasilkan bau, zat-zat bau harus dapat menguap sedikit larut dalam air dan sedikit dapat larut dalam lemak (Kartika, 1988).

Berdasarkan perhitungan analisis variansi (lampiran 15) terhadap analisis uji skala hedonik pada atribut aroma diketahui bahwa faktor konsentrasi fortifikan berbeda nyata terhadap beras fortifikasi sehingga perlu dilakukan uji lanjut. Sedangkan faktor varietas beras dan interaksinya tidak berbeda nyata terhadap beras fortifikasi. Hasil uji lanjut dapat dilihat pada Tabel 9.

Tabel 9. Pengaruh Konsentrasi Fortifikan terhadap Nilai Kesukaan Aroma pada Beras Fortifikasi

\begin{tabular}{|c|r|}
\hline Konsentrasi fortifikan (F) & Rata-rata (taraf 5\%) \\
\hline f3 (21\%) & 3,859 a \\
f2 (14\%) & 4,399 b \\
f1 (7\%) & $4,741 \quad \mathrm{c}$ \\
\hline
\end{tabular}

Dari Tabel 9 diatas, dapat diketahui bahwa dalam hal aroma beras fortifikasi yang dihasilkan, semakin kecil konsentasi fortifikan yang diberikan lebih disukai panelis.

Rasa

Rasa sangat berperan dalam tingkat penerimaan masyarakat terhadap suatu bahan pangan. Umumnya bahan pangan tidak hanya terdiri dari satu macam rasa tetapi merupakan gabungan berbagai macam rasa secara terpadu sehingga menimbulkan cita rasa yang utuh. Rasa suatu bahan pangan merupakan hasil kerjasama indera-indera yang lain. Indera penglihatan, pembauan, pendengaran dan perabaan ikut berperan dalam pengamatan rasa bahan pangan (Kartika, 1988). Penentuan rasa pada uji organoleptik dilakukan dengan cara memasak beras fortifikasi.

Berdasarkan perhitungan analisis variansi (Lampiran 16) terhadap analisis uji skala hedonik pada atribut rasa diketahui bahwa konsnetrasi fortifikan, varietas beras dan interaksinya tidak berbeda nyata terhadap nasi fortifikasi.

Berdasarkan hasil penelitian dapat diambil kesimpulan sebagai berikut:

1. Konsentrasi larutan fortifikan berpengaruh terhadap kadar protein, kadar besi dan kadar tiamin pada beras fortifikasi.

2. Varietas beras berpengaruh terhadap kadar protein, kadar besi dan kadar tiamin pada beras fortifikasi

3. Interaksi antara konsentrasi larutan fortifikan dan varietas beras berpengaruh terhadap kadar protein dan kadar tiamin pada beras fortifikasi.

4. Semakin tinggi konsentrasi larutan fortifikan yang diberikan maka menghasilkan semakin tinggi kadar protein, kadar besi dan kadar tiamin.

5. Hasil uji hedonik untuk beras fortifikasi dalam atribut warna menunjukkan bahwa konsentrasi fortifikan dan interaksinya tidak berpengaruh nyata terhadap beras fortifikasi. Sedangkan faktor varietas beras berpengaruh nyata terhadap beras fortifikasi. Dalam atribut aroma menunjukkan bahwa konsentrasi fortifikan berpengaruh nyata terhadap beras fortifikasi sedangkan faktor varietas beras dan interaksinya tidak berpengaruh nyata terhadap beras fortifikasi. Dan dalam atribut rasa untuk nasi fortifikasi menunjukkan bahwa konsentrasi fortifikan, varietas beras dan interaksinya tidak berpengaruh nyata terhadap nasi fortifikasi.

\section{Daftar Pustaka}

1. Adriana, Elva Dissa. Tri Aminingsih. Agustino Zulys. 2015. Efektifitas fortifikasi zat besi NaFeEDTA dan fero fumarat pada pangan berbasis kedelai melalui uji bioavailabilitas secara in vitro. Universitas Pakuan: Bogor.

2. AKG. 2013. Angka Kecukupan Gizi 2013 bagi Masyarakat Indonesia. Jurnal. Jakarta

3. Almatsier, S. 2009. Prinsip Dasar Ilmu Gizi. Jakarta: Penerbit PT Gramedia Pustaka Utama.

4. Andarwulan, N. dan S.Koswara. 1992. Kimia Vitamin. Penerbit: Rajawali. Jakarta

5. AOAC, 2005. Official Methods of Analysis of The Association of AnalyticalChemists, Washington D.C.

6. Badarudin, T. 2006. Penggunaan maltodekstrin pada yoghurt bubuk ditinjau dari uji kadar air keasaman, pH, rendemen,reabsoprsi uap air, kemampuan keterbasahan, dan sifat kedispersian. Skripsi. Prodi Teknologi Hasil Ternak, Fak. Peternakan Universitas Brawijaya.

7. Balai Besar Penelitian Tanaman Padi. 2009. Deskripsi Varietas Padi. Balai Penelitian dan Pengembangan Pertanian

8. Buckle, K. A., R. A. Edwards, G. H. Fleet, and M Wotton. 1987. Ilmu Pangan. Terjemahan: H. Purnomo dan Adiono. Universitas Indonesia Press, Jakarta.

9. BSN. 2015. SNI 6128. Beras. Jakarta.

10. Cahyadi,Wisnu dan Yusep Ikrawan. 2014. Pengembangan Mikroenkapsulasi Iodium, Besi dan Vitamin A Untuk Fortifikasi Beras Dalam Upaya Penanggulangan Kekurangan Zat Gizi Mikro. Bandung: UNPAS

11. Darlan, Ar. 2012. Fortifikasi Dan Ketersediaan Zat Besi Pada BahanPangan Berbasis Kedelai dengan Menggunakan Fortifikan FeSO4.7H2O Campuran FeSO4.7H2O + Na2H2EDTA.2H2O dan NaFeEDTA.Tesis. Program Pasca Sarjana. Departemen Kimia, FMIPA-Universitas Indonesia. Depok.

12. Departemen Kesehatan RI. 2012. Angka Kecukupan Gizi Yang Dianjurkan Bagi Bangsa Indonesia. Keputusan Menteri Kesehatan. 
13. Direktorat Gizi Departemen Kesehatan RI,2012. Daftar Komposisi Bahan Makanan. Jakarta : Departemen Kesehatan.

14. Fidler, M.C.2003. Optimizing The Absorption Of Fortification Iron. Dissertation.Diss ETH No.15113. Swiss Federal Institute Of Technology, Zurich

15. Gaspersz, Vincent. 2006. Teknik Analisis dalam Penelitian Percobaan Jilid I, Penerbit Tarsito. Bandung

16. Hardinsyah dan D. Martianto. 1989. Menaksir kecukupan Energi dan Protein Serta Penilaian Menu Gizi Konsumsi Pangan. Wisari : Jakarta.

17. Haryadi. 2008. Teknologi Pengolahan Beras. Yogyakarta: UGM Press

18. Kartika, B., H, Pudji., dan S, Wahyu. 1998. Pedoman Uji Inderawi Bahan Pangan. Penerbit UGM, Jogjakarta.an Gizi dan Makanan.

19. Komari dan Hermana. 1995. Fortifikasi Zat Besi Pada Tepung Terigu dan Kecap. Jurnal Penelitan.

20. Koswara, Sutrisno. 2009. Teknologi Pengolahan Beras (Teori dan Praktek). E-book pangan.

21. Leskova, E, K Jana K. Eva, K martina, P. Janka, and H.I Kristina. 2006. (Jordan 2003 ; Settembre et al ; Nosaka 2006). Vitamin losses: retention during heat treatment and continual changes expressed by mathematical models.Journal of Food Composition and Analysis 19:252.276.

22. Rohman dan Sumantri. 2007. Analisis Makanan. Universitas Gadjah Mada.Press: Yogyakarta.

23. Sihotang, Elsa. 2014. Fortifikasi Makanan Untuk Mengatasi Permasalahan Gizi Mikro. Bandung: Politeknik Kesehatan Kemenkes.

24. Soekarto,dkk. 1985. Penilaian Organoleptik untuk Industri Pangan dan Hasil Pertanian. Jakarta: Bharata Karya Aksara.

25. Surahman, D. N. 2014 .Stabilitas Zat Gizi Mikro (Iodium dan Fe) Selama Proses Pengolahan Pada Beras Fortifikasi. Bandung : Universitas Pasundan.

26. Villareal C and B. Juliano. 1989. Variability in contents of thiamin and riboflavin inbrown rice. Crude oil in brown rice and bran-polish, and silicon in hull of IR rices. Plants Foods for Human Nutrition 39:287-297.

27. WHO and Agriculture Organization of the United Nations. 2006. Guidelines on food fortification with micronutrients.

28. Wieringa FT, Laillou A, Guyondet C, Jallier V, Moench-Pfanner R, Berger J. 2014. Stability and retention of micronutrients in fortified rice prepared using different cooking methods. Ann N Y Acad Sci. 1324:40-47.

29. Winarno F.G., 2002. Kimia Pangan dan Gizi. Gramedia, Jakarta.

30. Yudha KB. 2008. Optimasi Formulasi Mikroenkapsulasi Minyak Sawit Merah Menggunakan Pektin, Gelatin, dan Maltodekstrin Melalui Proses Thin Layer Drying. Skripsi. Bogor: Departemen Ilmu dan Teknologi Pangan Fakultas Teknologi Pertanian. Institut Pertanian Bogor.

31. Yuliani,S. 2011. Mikroenkapsulasi: Pendekatan strategis untuk fortifikasi pangan, Buletin teknologi Pascapanen pertanian, 7:9-19. 